\title{
PEMBERDAYAAN KARANG TARUNA DALAM MENINGKATKAN KEMANDIRIAN PEMUDA DI WILAYAH PENUTUPAN LOKALISASI MOROSENENG DI SURABAYA
}

\author{
Woro Utari' ${ }^{1}$ Mei Indrawati², Karlin $^{3}$ \\ ${ }^{1}$ Universitas Wijaya Putra \\ ${ }^{2}$ Universitas Wijaya Putra \\ ${ }^{3}$ Universitas Wijaya Putra
}

woroutari@uwp.ac.id, meiindrawati@uwp.ac.id, karlin@uwp.ac.id

\begin{abstract}
Abstrak
Tujuan Program Pengabdian Masyarakat /PPM ini adalah (1) untuk meningkatkan kemandirian pemuda dalam bentuk peningkatan kemampuan dan ketrampilan berwirausaha dalam mengelola suatu organisasi, (2) meningkatkan keberanian untuk melakukan hal-hal dan usaha baru di wilayah terdampak penutupan Lokalisasi Moroseneng. (3) untuk meningkatkan pendapatan masyarakat. Pelakasanaan PPM ini bertempat di Kelurahan Sememi, Kecamatan Benowo. Metode yang digunakan dalam pelaksanaan program pemberdayaan ini melalui penyuluhan, pelatihan dan pendampingan. Hasil pelaksanaan kegiatan ini antara lain; (1) terlaksananya kegiatan pertemuan antara ketua karang taruna beserta anggota dan Lurah Sememi, (2) Terlaksananya kegiatan pelatihan penyusunan rencana bisnis. (3) Terlaksananya kegiatan pelatihan manajemen pemasaran dan manajemen keuangan. (4) Dilaksanakannya pelatihan dan praktek sablon kaos, serta praktek pengelasan dan pembuatan layang layang hias. (5) adanya peningkatan pendapatan mitra.
\end{abstract}

Kata Kunci : Karang Taruna, Pemberdayaan, Kemandirian

\section{PENDAHULUAN}

Surabaya sebagai kota metropolitan dan kota terbesar setelah Jakarta menyimpan banyak permasalahan, salah satunya adalah prostitusi. Prostitusi merupakan salah satu permasalahan yang tidak hanya dihadapi oleh Kota Surabaya, namun juga dihadapi oleh berbagai kabupaten kota di wilayah Indonesia. Permasalahan ini membutuhkan perhatian khusus untuk mengatasinya. Sebagaimana yang dilakukan oleh DKI Jakarta, maka Pemerintah Kota Surabaya juga memiliki komitmen dalam memberantas prostitusi dengan cara melakukan penutupan semua lokalisasi yang ada di Kota Surabaya secara bertahap di tahun 2013, yaitu lokalisasi Kermil Tambakasri, lokalisasi Dupak Bangunsari, lokalisasi Dolly-Jarak dan lokalisasi Moroseneng (Klakahrejo-Sememi). Penutupan lokalisasi ini, menurut Wali Kota Surabaya Tri Rismaharini adalah untuk menyelamatkan masa depan anak-anak Surabaya yang tinggal di sekitar lokalisasi.

Meskipun keberadaan lokalisasi Moroseneng yang terletak di Kelurahan Kandangan dan Kelurahan Sememi, membawa dampak positif terhadap perekonomian di Kecamatan Benowo,

Ekonomi, Sosial dan Budaya

1259 
namun pemerintah Kota Surabaya tetap memiliki komitmen untuk menutupnya. Dampak positif lokalisasi adalah banyaknya masyarakat sekitar yang menggantungkan kehidupannya pada lokalisasi. Hampir semua lapisan masyarakat menikmati peningkatan perekonomian mulai dari tukang parkir, mucikari, penjual kelontong, loundry, penjual makanan dan minuman tukang ojek dll. Kondisi ini menjadikan masyarakat semakin sejahtera.

Ketika Pemerintah Kota Surabaya menutup lokalisasi ini, warga yang menggantungkan hidupnya dilokalisasi menolak akan kebijakan tersebut, hal ini karena masyarakat sekitar yang bermata pencaharian di lokalisasi secara langsung akan terhenti. Akibat yang ditimbulkan dari penutupan lokalisasi itu tidak hanya pada perekonomian masyarakat akan tetapi juga berakibat pada kehidupan sosial masyarakat.

Penutupan ini membawa dampak yang sangat besar kepada masyarakat sekitar, terutama pemuda di kawasan terdampak, yaitu di Kelurahan Kandangan dan Kelurahan Sememi Kecamatan Benowo Kota Surabaya. Para pemuda yang sebelumnya bekerja di wisma-wisma sebagai pramusaji, tukang parkir, pedagang rokok, pedagang minuman, satpam, pedagang keliling, dan lain-lain, dengan adanya penutupan lokalisasi "Moroseneng" mereka kehilangan pekerjaan. Bahkan sampai sekarangpun masih ada pemuda yang belum mendapatkan pekerjaan.

Kehidupan sebelum penutupan lokalisasi merupakan kehidupan yang sangat menjanjikan, begitu mudahnya para pemuda mendapatkan penghasilan dari situ. Kondisi ini menjadikan para pemuda terlena dengan kehidupan yang menguntungkan, sehingga mereka menjadi pemuda yang tidak produktif dan tidak kreatif serta tidak mampu menunjukkan jati dirinya sebagai generasi muda.

Dampak penutupan lokalisasi sangat dirasakan oleh semua masyarakat disekitar wilayah terdampak, termasuk para pemuda. Para pemuda kehilangan mata pencahariannya, sementara mereka tidak memiliki ketrampilan yang bisa di tawarkan ke dunia kerja. Karang Taruna sebagai salah satu organisasi penggerak pembangunan pemuda di kelurahan perlu menunjukkan perannya untuk membantu dalam mengatasi berbagai masalah yang dihadapi pemuda terutama yang berkaitan dengan upaya untuk menciptakan pemuda produktif. Adapun peran Karang Taruna dalam membantu menciptakan kemandirian pemuda antara lain dengan memfasilitasi kegiatan pelatihan untuk meningkatkan keterampilan pemuda dalam menguasai keahlian dalam bidang tertentu. Diharapkan dengan memiliki ketrampilan yang memadai maka para pemuda akan mampu bersaing di dunia kerja, atau mereka akan mampu menjadi pemuda yang mandiri dengan membuka usaha atau membuka lapangan kerja baru.

\section{Upaya yang dilakukan oleh Karang Taruna} dalam mengaktualisasikan diri dengan cara memperbaiki dan meningkatkan kinerja organisasinya sehingga mampu membantu menciptakan pemuda produktif. Semua anggota Karang Taruna wajib bahu membahu untuk merancang program yang sifatnya membantu pemuda dalam meningkatkan kualitas hidupnya. Dengan cara ini maka potensi Karang Taruna dapat dikembangkan serta dirasakan manfaatnya oleh pemuda sehingga upaya mewujudkan pemuda produktif dapat tercapai.

Yamani dalam Puluhulawa (2012) menyatakan bahwa ada beberapa ciri yang menunjukkan pemuda produktif yaitu; 1) inovatif dan kreatif, 2) memiliki semangat untuk berusaha, dan 3) komitmen terhadap pekerjaan. Ketiga ciri ini tidak dimiliki oleh oleh pemuda di Kelurahan Kandangan dan Sememi, yang artinya bahwa para pemudanya bukan termasuk kategori pemuda produktif.

Banyaknya pemuda yang putus sekolah dan pengangguran merupakan dampak dari penutupan lokalisasi yang perlu mendapat fasilitas agar memiliki berbagai keterampilan sesuai dengan yang telah diprogramkan. Pemuda putus sekolah dan pemuda pengangguran dapat memilih keterampilan tertentu untuk dikembangkan dan selanjutnya mereka dilatih dan dikembangkan komitmennya untuk memiliki jiwa inovatif dan kreatif, semangat untuk berusaha, dan komitmen terhadap pekerjaan yang dilakukan, oleh karena itu perlu adanya pemberdayaan pemuda. Pemberdayaan masyarakat

$$
\text { Ekonomi, Sosial dan Budaya }
$$


adalah upaya untuk memampukan dan memandirikan masyarakat (Fahrudin, 2012)

Hasil pengamatan yang dilakukan menunjukkan bahwa Karang Taruna di Kelurahan Kandangan dan Sememi belum optimal dalam melaksanakan perannya sebagai pemuda produktif. Dalam konteks ini upaya untuk menciptakan pemuda produktif belum menjadi program utama Karang Taruna yang ada di Kelurahan Kandangan dan Kelurahan Sememi Kecamatan Benowo Kota Surabaya. Mereka lebih banyak memfasilitasi kegiatan pengembangan demokrasi dan cenderung mengabaikan upaya untuk memberdayakan potensi pemuda melalui penciptaan pemuda produktif. Hal ini yang menjadikan karang taruna sebagai salah satu organisasi kemasyarakatan kurang memberi peran dalam membantu menciptakan pemuda produktif.

Banyaknya pemuda yang menganggur pasca penutupan lokalisasi menunjukkan bahwa para pemuda tersebut masih belum mampu meningkatkan kesejahteraannya. Berdasarkan data dari Dinas Tenaga Kerja dan Mobilisasi Penduduk Kota Surabaya Tahun 2015 menunjukkan bahwa jumlah pencari kerja masih cukup tinggi, dimana ada 16.891 pencari kerja, jumlah ini turun dibandingkan tahun sebelumnya yaitu sebesar 18.677 pencari kerja. Table berikut menunjukkan banyaknya para pencari kerja

Tabel 1 Banyaknya Pencari Kerja Baru berdasarkan pendidikan terakhir tahun 2015

\begin{tabular}{|c|c|c|c|c|c|}
\hline Rincian & SD & SMP & SMA & AK/PT & Jumlah \\
\hline $\begin{array}{l}\text { Sisa Pencari Kerja yang belum ditempatkan akhir } \\
\text { tahun } 2013\end{array}$ & 26 & 59 & 5,643 & 12,949 & 18,677 \\
\hline Jumlah Pencari Kerja Pendaftar Baru & 29 & 180 & 3,372 & 3,883 & 7,464 \\
\hline Jumlah Pencari Kerja yang ditempatkan & 38 & 189 & 3,732 & 1,266 & 5,225 \\
\hline Jumlah Pencari Kerja yang dihapus & 6 & 25 & 867 & 3,127 & 4,025 \\
\hline $\begin{array}{lcccc}\text { Jumlah } & \text { Pencari } & \text { Kerja } & \text { yang } & \text { belum } \\
\text { ditempatkan pada akhir tahun } & 2014 & \\
\end{array}$ & 11 & 25 & 4,416 & 12,439 & 16,891 \\
\hline
\end{tabular}

Sumber : BPS Surabaya, 2016

Tabel di atas menunjukkan jumlah para pencari kerja yang ada di Kota Surabaya, termasuk di kecamatan Benowo sebagai dampak penutupan lokalisasi.
Banyaknya para pencari kerja yang ada di Kota Surabaya disebabkan karena banyaknya pengangguran dan putus sekolah. Berikut ini data pemuda yang menganggur dan putus sekolah di Kecamatan Benowo.

Tabel 2 Data Jumlah Pemuda Pengangguran dan Putus Sekolah di Kelurahan Kandangan dan Kelurahan Sememi

\begin{tabular}{cccccc}
\hline \multirow{2}{*}{ No } & \multirow{2}{*}{ Tahun } & \multicolumn{2}{c}{ Kelurahan Kandangan } & \multicolumn{2}{c}{ KelurahanSememi } \\
\cline { 3 - 6 } & & Pengangguran & Putus Sekolah & Pengangguran & Putus Sekolah \\
\hline 1 & 2013 & 14 & 3 & 23 & 6 \\
\hline 2 & 2014 & 43 & 2 & 52 & 3 \\
\hline 3 & 2015 & 35 & 0 & 38 & 0 \\
\hline
\end{tabular}

Sumber : Kecamatan Benowo, 2017

Berdasarkan tabel di atas diketahui bahwa jumlah Pemuda Pengangguran dan Pemuda Putus Sekolah di Kelurahan Kandangan dan Kelurahan Sememi Kecamatan Benowo mengalami peningkatan terutama pasca penutupan lokalisasi. Hal ini menunjukkan bahwa karang taruna sangat dituntut untuk menunjukkan perannya dalam memberikan keterampilan kepada pemuda pengangguran tersebut agar mampu berkiprah dalam mengembangkan kemampuannya sehingga memiliki keterampilan yang memadai dan dapat bersaing dalam memasuki dunia pekerjaan.

\section{Permasalahan Mitra, alternative solusi dan hasil}

Permasalahan yang dihadapi oleh Karang Taruna di Kelurahan Kandangan dan Kelurahan Sememi secara umum sama, yaitu permasalahan dari

$$
\text { Ekonomi, Sosial dan Budaya }
$$




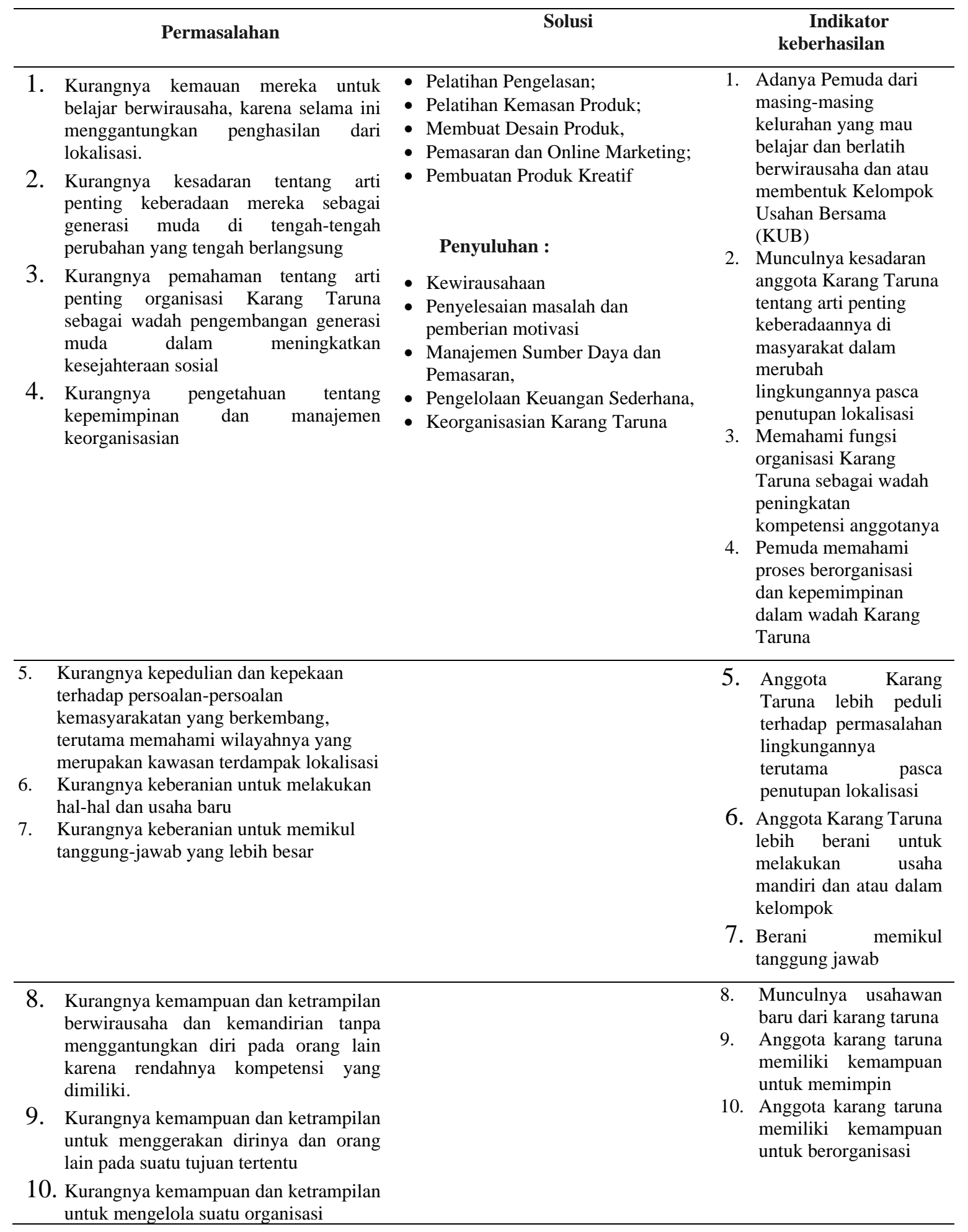




\section{METODE}

Ada beberapa tahapan yang dilakukan dalam upaya untuk menyelesaikan permasalahan yang dihadapi oleh anggota Karang Taruna dalam rangka pemberdayaan generasi muda.

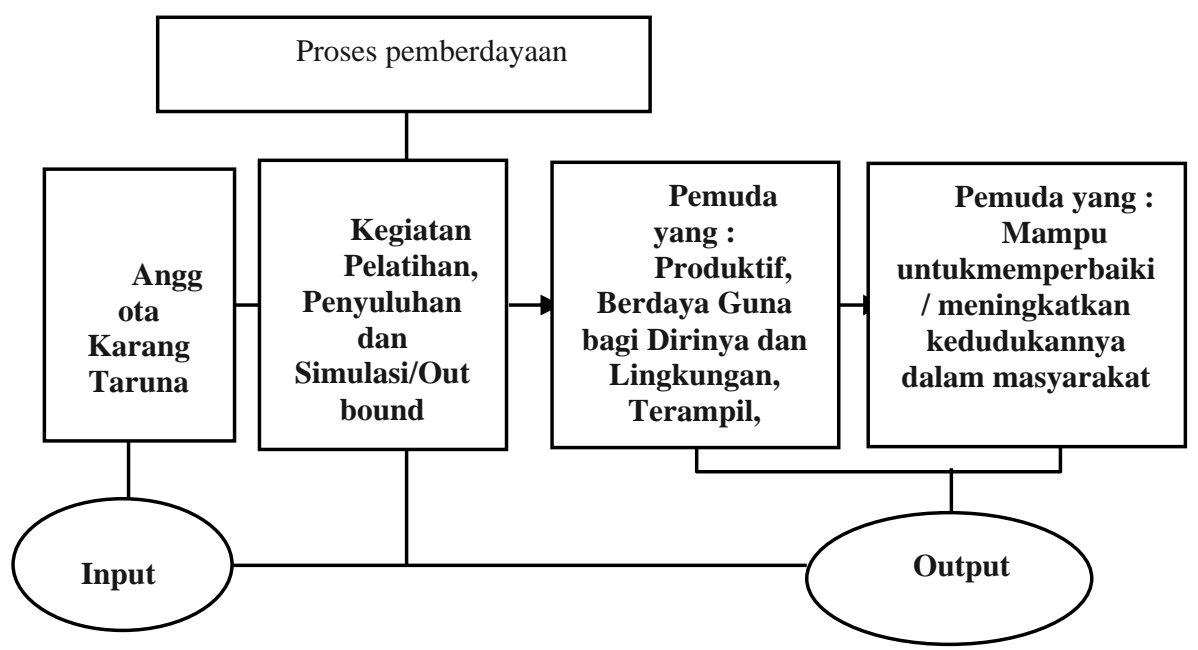

Adapun tahapan yang ditempuh untuk menyelesaikan masalah dalam rangka pemberdayaan generasi muda dapat digambarkan sebagai berikut :

Gambar 3.1 Langkah-Langkah Penyelesaian Masalah dalam PKM

\section{Pendekatan yang Ditawarkan}

Metode pengembangan dan pemberdayaan generasi muda yang dilakukan dalam uoaya untuk meningkatkan kemandirian pemuda di Kelurahan Sememi dan Kelurahan Kandangan dalam bentuk penyuluhan, pelatihan dan pendampingan. Penyuluhan dan pelatihan yang dilakukan, tentunya, diorientasikan pada pemenuhan dimensi kognitif, afektif dan psikomotor. Dengan demikian diharapkan melalui pelatihan-pelatihan yang dilaksanakan, generasi muda yang tergabung dalam wadah organisasi Karang Taruna memiliki kemampuan dan keterampilan untuk berwirausaha mandiri dan mampu bekerja untuk menjadikan dirinya lebih berdaya guna, memiliki ketrampilan

\section{HASIL DAN PEMBAHASAN}

Upaya yang dilakukan dalam rangka untuk meningkatkan kemandirian pemuda diantaranya adalah dengan memberikan pelatihan. Kegiatan pemberdayaan Karang Taruna dilakukan dengan harapan menjadikan generasi muda yang produktif, terampil, responsive dan berdaya guna bagi diri dan lingkungannya, yang terbagi dalam tiga tahapan menggerakkan dan mengelola usaha bersama, memiliki kesadaran yang tinggi akan eksistensi dirinya di tengah-tengah masyarakat dan perubahan, empati terhadap sesama dan lingkungan, keberanian berkreasi dan berinovasi.

Adapun materi penyuluhan dan pelatihan yang disampaikan kepada Karang Taruna adalah Kewirausahaan, Success Story, Problem Solving \& Motivasi, Manajemen SDM dan manajemen Pemasaran. Sedangkan pelatihan usaha diantaranya; Pengelasan (kanopi, pagar, dll), Pelatihan Sablon Kaos dan Kemasan, Pembuatan produk kreatif, Pelatihan Pembuatan Desain Produk dan Kemasan Produk, Pelatihan Pemasaran dan E-Marketing dan Pengelolaan Keuangan Sederhana

(Soekanto, 1987) yaitu tahap pra pelaksanaan, tahap pelaksanaan dan tahap evaluasi dan monitoring.

Tahap pra pelaksanaan, pada tahap ini kegiatan yang dilaksanakan meliputi kegiatan koordinasi dan silaturrahmi dengan Lurah Kandangan Kecamatan Benowo dan pengurus Karang Taruna yang menjadi sasaran program untuk menyusun ulang rencana kegiatan disesuaikan 
dengan alokasi dana yang tersedia dan kebutuhan terkini dari mitra.

Selanjutnya pada tahap pelaksanaan, kegiatan yang dilakukan dalam bentuk penyuluhan (ceramah dan tanya jawab) dan pelatihan untuk meningkatkan ketrampilan dan kompetensi.Tahap evaluasi dan monitoring adalah kegiatan-kegiatan yang dilakukan untuk memonitoring dampak dari penyuluhan dan pelatihan yang telah diberikan.

Kegiatan yang dilaksanakan sampai dengan laporan ini dibuat antara lain; terlaksana sosialisasi program dan testimony ke anggota karang taruna, terlaksana pelatihan dan praktek las dalam pembuatan kerajinan layang-layang hias, terlaksana pelatihan dan praktek sablon kaos, terlaksana pelatihan penyusunan rencana bisnis dan pelatihan manajemen pemasaran. Rencana kegiatan selanjutnya adalah pelatihan manajemen keuangan, manajemen SDM, perijinan dan akses permodalan, motivasi dan pendampingan usaha agar pelatihan yang diberikan dipastikan berjalan dan menjadi usaha mandiri.

\section{Berikut ini kegiatan yang telah dilaksanakan :}

\section{Pertemuan dengan pengurus Karang Taruna}

Pada tahap pra pelaksanaan ini, tim pelaksana terlebih dahulu bertemu dengan pengurus karang taruna RW. 09 Kelurahan Kandangan yaitu Saudara Zakaria Antoni selaku ketua Karang Taruna. Dalam pertemuan yang dilaksanakan di kantin kantor tempat beliau bekerja tersebut, beliau menyampaikan terima kasih atas perhatian dari tim pelaksana karena bersedia membantu anggota karang taruna untuk berwirausaha mandiri dan mengembangkan usaha yang sudah ada yaitu pembuatan layang-layang hias, namun usaha tersebut berjalan hanya beberapa minggu namun kemudian mati meskipun potensinya sangat besar. Layang-layang hias tersebut digunakan untuk menghias kota. Selain itu, karang taruna dari RT. 02 RW. 09 meminta untuk diberikan pelatihan sablon kaos karena mereka memandang selama ini di Surabaya belum ada produsen kaos oleh-oleh kas Surabaya yang harganya murah dan bisa dibeli dalam jumlah besar/partai.

Selanjutnya, tim pelaksana bertemu dengan

Lurah Kandangan Kecamatan Benowo Kota Surabaya. Pertemuan ini dilaksanakan di Kantor
Lurah Kandangan. Pak Lurah menyampaikan ucapan terima kasih kepada Universitas Wijaya Putra dan Tim Pelaksana karena bersedia membantu masyarakat Moroseneng yang sejak dulu tercitrakan negatif untuk lebih berdaya melalui pemberdayaan karang taruna. Pak Lurah menyetujui dan memberikan dukungan kepada semua program yang akan dilaksanakan dan menyarankan untuk turut juga membantu mempercantik lingkungan di RW. 09 agar tidak terkesan kumuh dan masih seperti dulu. Beliau mengusulkan untuk dibuatkan hiasanhiasan yang bisa menjadi ikon dan mempercerah kampong Moroseneng.

\section{Sosialisasi program dan testimoni ke anggota karang taruna}

Kegiatan ini dilaksanakan di Balai RT. 02 RW. 09 Kelurahan Kandangan, dihadiri oleh 30 orang anggota Karang Taruna dan beberapa anggota PKK yang sangat ingin tahu kegiatan tim pelaksana. Dalam pertemuan ini, tim pelaksana menjelaskan tentang tujuan dan program yang akan dilaksanakan, serta menampung aspirasi dari anggota karang taruna.

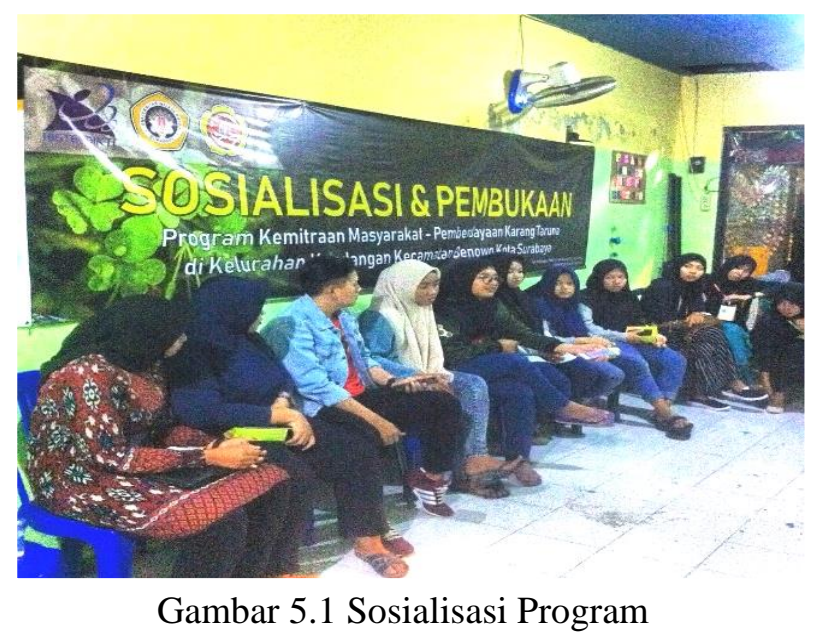

\section{Open Mind Wirausaha, Motivasi dan Penyerahan Peralatan Latihan}

Kegiatan didahului dengan motivasi berwira usaha yang disampaikan oleh Ibu Karlin, SE., M.Ak. dosen Program Studi Akuntansi yang juga seorang motivator. Dalam materinya beliau banyak menekankan untuk menjadikan berwirausaha sebagai sebuah kebutuhan bukan sekedar keinginan,

$$
\text { Ekonomi, Sosial dan Budaya }
$$


sehingga akan selalu termotivasi untuk mengembangkan usaha. Selain itu, beliau juga menyampaikan tentang beberapa tips untuk menjaga semangat wirausaha. Dalam sesi ini juga

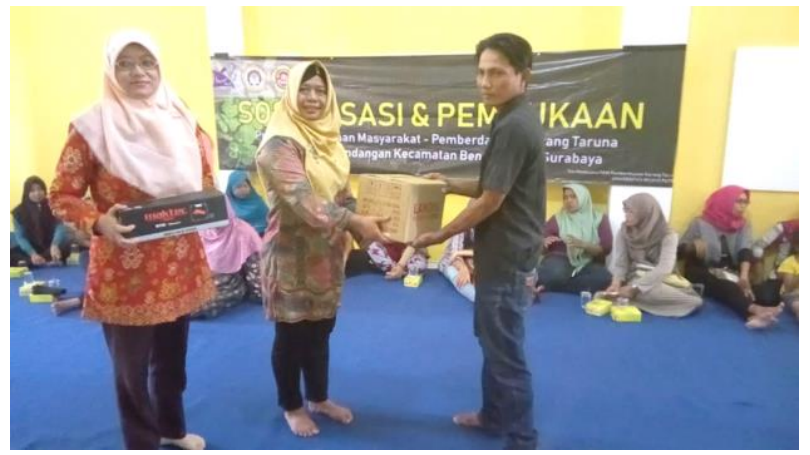

disampaikan peralatan kerja dan praktek oleh ketua tim pelaksana Dr. Woro Utari kepada perwakilan anggota karang taruna. Peralatan tersebut antara lain; mesin las, gerinda dan gunting beton. Peralatan tersebut juga akan digunakan sebagai sarana pelatihan dan praktek membuat layang-layang hias.

\section{Gambar 5.2 Open Mind dan Penyerahan Peralatan Latihan}

Pada pertemuan ini disepakati kegiatan pelatihan yang akan dilaksanakan adalah pelatihan las dan sablon kaos, pelatihan manajemen dan perencanaan bisnis serta menghias kampong. Pada pertemuan ini juga tim pelaksana menghadirkan tokoh pemuda Bapak Gandung Istanto, ST. yang berhasil berwirausaha sehingga menjadi mandiri dan memiliki karyawan pada usaha yang digelutinya yaitu las dan pembuatan alat peraga pendidikan. Pertemuan ini juga menyepakati tentang jadwal kegiatan dan pendampingan.

\section{Pelatihan dan praktek sablon kaos}

Pada pelatihan ini, peserta diberikan pembekalan tentang teknik penyablonan dan sablon press oleh pengusaha kaos di Surabaya, Bapak Antok. Kegiatan ini diikuti oleh anggota karang taruna dari RT. 02 RW. 09 Kelurahan Kandangan yang diawal pelatihan berjumlah 10 orang. Dalam pelatihan ini diajarkan tentang teknik dasar sablon pada kain, teknik pengepresan dan pemilihan bahan kain dan sablon. Peserta cukup antusias mengikuti sesi ini yang pada hari berikutnya mereka mencoba mempraktekkan sablon kaos.

\section{Pelatihan dan praktek las dalam pembuatan kerajinan layang-layang hias}

Pelatihan ini ditujukan agar anggota karang taruna mampu menciptakan lapangan kerja sendiri dan melanjutkan usaha yang pernah berjalan yaitu pembuatan layang-layang hias. Selanjutnya dilaksanakan pelatihan las yang disampaikan oleh Bapak Gandung bertempat di bengkel Fakultas Teknik UWP, yang mengajarkan teknik dasar las, peralatan yang digunakan, pemilihan bahan, cara pengelasan dan menghitung standar kekuatan las serta diajarkan juga tentang prosedur keamanan dan kesehatan kerja di bidang las. Setelah diajarkan peserta diajak untuk mempraktekkan las pada bahan yang disediakan.

Berikutnya, peserta mempraktekkan las di kampungnya dengan membuat layang-layang hias. Layang-layang hias ini selain untuk praktek juga digunakan untuk menghias kampung dengan tambahan bantuan dana dari Bapak Camat Benowo. Untuk awal praktek mereka membuat 15 unit layanglayang, yang akan ditempatkan dibeberapa tempat di RW. 09 Kelurahan Kandangan.

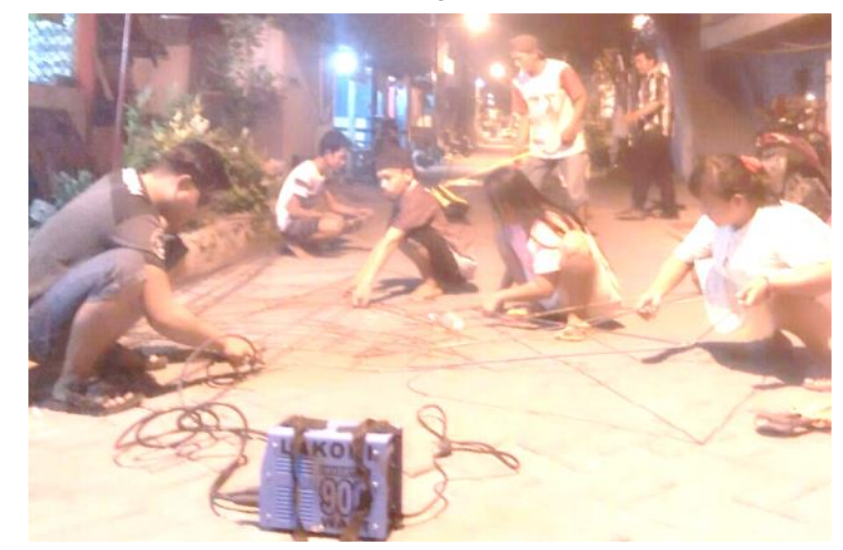

Gambar 5.3 praktek pembuatan layang-layang hias

Sampai dengan saat ini, proses praktek masih berlangsung dengan pengerjaan layang-layang hias.

\section{Pelatihan penyusunan rencana bisnis}

Pada sesi ini peserta diajari cara membuat proposal usaha dan bagaimana memenangkan benak konsumen untuk kemudian order barang yang kita jual. Diajarkan juga bagaimana cara menyusun company profile usaha dan rencana bisnis mulai dari perencanaan keuangan, SDM, bahan baku dan Ekonomi, Sosial dan Budaya 
supplier, distribusi, pemasaran, dan lain-lain dengan menggunakan metode Business Model Canvas (BMC). Peserta diajak untuk memahami tentang bagaimana mengisi kanvas bisnis untuk memulai usaha agar cepat berhasil dengan memahami beberapa kunci, antara lain : (1) Value Proposition yang merupakan nilai atau value yang kita tawarkan untuk pelanggan dimana kita kelebihan dan keunggulan produk dibanding pesaing, (2) Customer segments, langkah kedua adalah mencari orangorang yang mungkin akan tertarik dengan value yang ditawarkan. Customer segments adalah penggolongan orang-orang yang mungkin tertarik dengan value proposition bisnis kita, (3) Customer Relationship yaitu cara-cara yang bisa digunakan untuk berkomunikasi dengan customer segments. Biasanya, banyak orang yang bingung membedakan antara customer relationship atau channels. Kata kuncinya adalah relationship. Customer relationship soal hubungan, kalau channel soal cara menjangkau customer segments. (4) Channels, adalah cara menjangkau customer. Tidak terbatas pada distribusi, tapi juga hal lainnya yang menyebabkan bisnis dan customer bisa bersentuhan. (5) Key activities harus diisi dengan kegiatan wajib yang dilakukan oleh perusahaan untuk menghasilkan value proposition yang ditawarkan. (6) Key resources adalah hal-hal paling penting yang harus Anda punyai agar key activities bisa dijalankan dan value proposition bisa diberikan pada customer. (7) Key partners adalah pihak-pihak yang bisa Anda ajak kerjasama, (8) Cost structure adalah rincian biayabiaya terbesar yang harus Anda keluarkan untuk melakukan key activities dan menghasilkan value proposition dan (9) Revenue stream dalam BMC akan kita isi dengan berbagai cara untuk menghasilkan keuntungan dari value proposition kita. Bahasa kasarnya: cara mendapatkan uang.

\section{Pelatihan manajemen pemasaran.}

Pada pelatihan ini, peserta diajarkan materi pemasaran baik pemasaran offline maupun online. Materi ini berisi tentang pemahaman peserta pada bauran pemasaran, yaitu bagaimana membuat produk yang menarik konsumen, bagaimana menghitung harga pokok produksi dan bagaimana menetapkan harga jual agar tetap untung, bagaimana menempatkan barang dan bagaimana agar barang sampai pada tangan konsumen dengan baik, bagaimana mempromosikan produk lewat saluransaluran yang ada dan murah seperti media website dan media sosial.

\section{KESIMPULAN}

$$
\begin{aligned}
& \text { Kesimpulan berisi rangkuman hasil kegiatan } \\
& \text { pengabdian kepada masyarakat dan } \\
& \text { implikasi dari kegiatan yang dilaksanakan. }
\end{aligned}
$$

\section{UCAPAN TERIMAKASIH (Bila ada)}

Ucapan terima kasih disampaikan kepada Direktorat Riset dan Pengengabdian kepada Masyarakat, Direktorat Riset dan Pengembangan, Kementerian Risett, Teknologi dan Pendidikan Tingi, Lembaga Layanan Pendidikan Tinggi Wilayah 7 Jawa Timur, Universitas Wijaya Putra dan Mitra pelaksanaan program ini.

\section{REFERENSI}

Suharto, Edi. 2005. Membangun masyarakat memberdayakan rakyat. Bandung: Refika Aditama.

Fahrudin, Adi. 2012. Pemberdayaan, Partisipasi dan Penguatan Kapasitas Masyarakat. Bandung: Humaniora.

Najiati, Sri, dkk. 2005. Pemberdayaan Masyarakat di Lahan Gambut. Bogor: Wetlands International.

Soekanto, Soerjono. 1987. Sosial Suatu Pengantar. Jakarta: Rajawali press.

Mardikanto, Totok. 2014. CSR (Corporate Social Responsibility)(Tanggungjawab Sosial Korporasi). Bandung: Alfabeta.

Hikmat, Harry. 2006. Strategi Pemberdayaan Masyarakat. Bandung: Humaniora. 